Click www.researchjournal.co.in/online/subdetail.html to purchase.

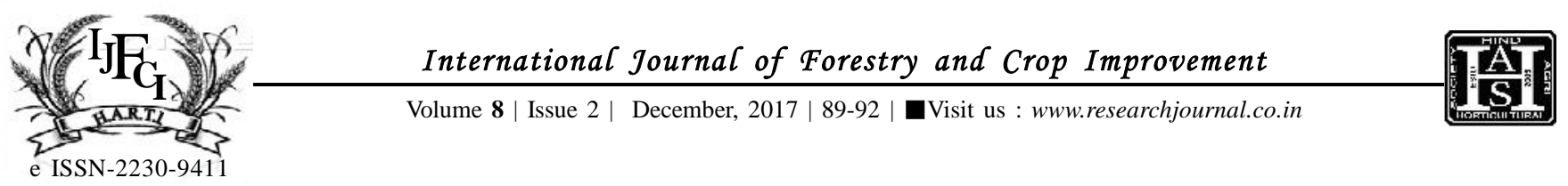

RESEARCH ARTICLE

DOI: $10.15740 / \mathrm{HAS} / \mathrm{IJFCI} / 8.2 / 89-92$

\title{
Effect of pruning levels of Glyricidia sepium on growth and productivity of field crops
}

\author{
H.Y. PATIL, S.M. MUTANALAND M.V. MOKASHI
}

\begin{abstract}
A field experiment was initiated at Main Agricultural Research Station, UAS, Dharwad from 2011-12 and 2012-13. Glyricidia sepium was grown at $10 \mathrm{~m}$ alley and planted at $1 \mathrm{~m}$ apart. Four pruning intensities were imposed on Glyricidia sepium alleys. Both groundnut and bengalgram crops were grown sequentially in the inter space of alleys. The groundnut pod yield and grain yield of bengalgram were significantly higher in Glyricidia pruned at 75 per cent of height as compared to the other pruning levels. Pruning of Glyricidia had significantly higher number of branches and total biomass with Glyricidia pruned 75 per cent of height as compared to other treatments. This may be due to higher number of branches and higher number of prunings.
\end{abstract}

KEY WORDS : Pruning, Coppicing, Glyricidia sepium, Alley

How TO CITE THIS ARTICLE : Patil, H.Y., Mutanal, S.M. and Mokashi, M.V. (2017). Effect of pruning levels of Glyricidia sepium on growth and productivity of field crops. Internat. J. Forestry \& Crop Improv, 8 (2) : 89-92, DOI: 10.15740/HAS/IJFCI/8.2/89-92.

Article Chronical : Received : 21.06.2017; Revised : 25.10.2017; Accepted : 05.11.2017

\section{MEMBERS OF RESEARCH FORUM}

Address of the Correspondence : S.M. MUTANAL, AICRP on Agroforestry, University of Agricultural Sciences, DHARWAD (KARNATAKA) INDIA

Email: mutanalsm@uasd.in

Address of the Coopted Authors : H.Y. PATIL AND M.V. MOKASHI, AICRP on Agroforestry, University of Agricultural Sciences, DHARWAD (KARNATAKA) INDIA 